\title{
ENPP3 Gene
}

National Cancer Institute

\section{Source}

National Cancer Institute. ENPP3 Gene. NCI Thesaurus. Code C147046.

This gene plays a role in phosphonucleotide metabolism. 